\title{
The effect of different levels of wheat bran on iron absorption in rats from bread containing similar amounts of phytate
}

\author{
By S. J. FAIRWEATHER-TAIT \\ Agricultural Research Council, Food Research Institute, Colney Lane, \\ Norwich, Norfolk NR4 7UA
}

(Received 26 May 1981 - Accepted 11 November 1981)

\begin{abstract}
1. Iron absorption was studied in weanling rats using balance techniques from semi-synthetic diets containing dried white bread (60.5 g dietary fibre $/ \mathrm{kg}$, White \& Southgate, unpublished results), brown bread (130.2 g dietary fibre $/ \mathrm{kg}$ ) or wholemeal bread $(221 \cdot 2 \mathrm{~g}$ dietary fibre $/ \mathrm{kg})$ at a level of $300 \mathrm{~g} / \mathrm{kg}$ and compared with a control group given a diet containing added $\mathrm{FeSO}_{4}$ at a similar $\mathrm{Fe}$ level to that for the bread groups. The dried bread contained 6.2-6.4 g phytate $/ \mathrm{kg}$.

2. Absorption of Fe was significantly higher $(P<0.001)$ in the control group $(0.45)$ than in the white $(0.28)$, brown $(0 \cdot 31)$ or wholemeal $(0 \cdot 24)$ groups.

3. A second experiment was carried out on 6-week-old rats in which the dried bread was extrinsically labelled with ${ }^{59} \mathrm{Fe}$ and absorption from a single meal measured by both faecal excretion and incorporation of ${ }^{59} \mathrm{Fe}$ into the blood. Control animals were given ${ }^{58} \mathrm{FeSO}_{4}$ for comparison.

4. The excretion of ${ }^{50} \mathrm{Fe}(\%$ of administered dose) was significantly lower $(P<0.001)$ in the control group (31) than in the white (48), brown (45) or wholemeal (47) groups. After $10 \mathrm{~d}$ the control group had significantly more ${ }^{59} \mathrm{Fe}$ in the blood than the bread groups, but there were no differences between the bread groups.

5. It appears that wheat bran fibre itself has no effect on the retention of Fe from the diet in the rat, when supplied in amounts similar to those found in commercially-available bread.
\end{abstract}

The relative importance of phytate and fibre in inhibting iron absorption is controversial. These studies were an attempt to investigate the effect of fibre alone on Fe absorption by varying the dietary level of wheat fibre but at the same time keeping the phytate level constant. This was done by adding appropriate amounts of sodium phytate to the flour (with due allowance for losses on baking) to equalize the final phytate concentration in the white, brown and wholemeal bread.

\section{MATERIALS AND METHODS}

Two experiments were carried out on rats to assess the effect of increasing levels of bran (baked into bread) on Fe absorption. The first was a balance study carried out over 2 weeks in which the intake and excretion of $\mathrm{Fe}$ from diets largely composed of dried bread were measured. The second was the measurement of $\mathrm{Fe}$ absorption from a single meal of dried bread, extrinsically labelled with ${ }^{59} \mathrm{Fe}$, compared with absorption from labelled $\mathrm{FeSO}_{4}$.

\section{Balance experiment}

This was designed as far as possible to follow the lines of a metabolic balance study carried out on human subjects at the Dunn Clinical Nutrition Centre, Cambridge, in which the same bread was used. Three types of bread were prepared with differing amounts of bran but similar phytate levels. They will be referred to as white, brown and wholemeal, and their composition is shown in Table $1 . \mathrm{FeSO}_{4}$ was added to the white and brown bread to bring the total $\mathrm{Fe}$ content up to that of the wholemeal bread.

A control diet was formulated which contained the same proportion of protein, fat and carbohydrate as the diet of the human subjects i.e. providing (\% total energy): protein 16 , fat 34 , carbohydrate 50 . These were supplied as albumen, maize oil and starch-sucrose $(50: 50, \mathrm{w} / \mathrm{w})$ respectively. The contribution of bread to the daily energy intake in the human 
Table 1. Composition of breads $(\mathrm{g} / \mathrm{kg} d r y w t)$

\begin{tabular}{lccc}
\hline & White & Brown & Wholemeal \\
\hline Total dietary fibre & $60 \cdot 5$ & $130 \cdot 2$ & $221 \cdot 2$ \\
(Non-cellulosic polysaccharides & $47 \cdot 6$ & $98 \cdot 4$ & $168 \cdot 2$ \\
Cellulose & $12 \cdot 9$ & $22 \cdot 0$ & $36 \cdot 3$ \\
Lignin) & $11 \cdot 0$ & $9 \cdot 8$ & $16 \cdot 7$ \\
Free sugars & $52 \cdot 3$ & $70 \cdot 9$ & $62 \cdot 5$ \\
Starch & $637 \cdot 0$ & $557 \cdot 0$ & $462 \cdot 0$ \\
Phytate & $14 \cdot 4$ & $14 \cdot 55$ & $14 \cdot 25$ \\
Iron $(\mu \mathrm{g} / \mathrm{g})$ & $67 \cdot 2$ & $62 \cdot 3$ & $64 \cdot 0$ \\
\hline \hline
\end{tabular}

Table 2. Composition of experimental diets $(\mathrm{g} / \mathrm{kg})$

\begin{tabular}{|c|c|c|c|c|c|}
\hline & Ingredients & Control diet & \multicolumn{2}{|c|}{ Bread diets } & \\
\hline & Albumen & 174.8 & \multicolumn{2}{|c|}{$130 \cdot 0$} & \\
\hline & Maize oil & $166 \cdot 4$ & \multicolumn{2}{|c|}{167.0} & \\
\hline & Starch & $299 \cdot 4$ & \multirow{2}{*}{\multicolumn{2}{|c|}{166.5}} & \\
\hline & Sucrose & $299 \cdot 4$ & & & \\
\hline & Dried bread & & \multicolumn{2}{|c|}{$\begin{array}{l}166.5 \\
310.0\end{array}$} & \\
\hline & Mineral mix* & $40 \cdot 0$ & \multicolumn{2}{|c|}{$40 \cdot 0$} & \\
\hline & Vitamin mix $\dagger$ & $20 \cdot 0$ & \multicolumn{2}{|c|}{$20 \cdot 0$} & \\
\hline \multicolumn{2}{|c|}{ Chemical composition } & Control & White & Brown & Wholemeal \\
\hline \multicolumn{2}{|c|}{ Protein $($ nitrogen $\times 6.25$ ) } & $134 \cdot 0$ & $149 \cdot 0$ & $147 \cdot 0$ & $145 \cdot 0$ \\
\hline \multicolumn{2}{|l|}{ Fat } & $164 \cdot 0$ & 168.0 & 167.0 & $169 \cdot 0$ \\
\hline \multicolumn{2}{|c|}{ Available carbohydrate } & $641 \cdot 0$ & $588 \cdot 0$ & 538.0 & $504 \cdot 0$ \\
\hline \multicolumn{2}{|c|}{ Total dietary fibre } & $4 \cdot 0$ & $16 \cdot 1$ & $38 \cdot 1$ & $72 \cdot 4$ \\
\hline \multicolumn{2}{|l|}{ Phytate } & 1.55 & $6 \cdot 3$ & $6 \cdot 3$ & $6 \cdot 4$ \\
\hline \multicolumn{2}{|l|}{$\mathrm{Fe}(\mu \mathrm{g} / \mathrm{g})$} & $24 \cdot 60$ & $22 \cdot 20$ & $21 \cdot 09$ & $21 \cdot 28$ \\
\hline
\end{tabular}

* Mineral mix (g/kg diet): calcium hydrogen phosphate $13 \cdot 00$, calcium carbonate $8 \cdot 20$, potassium chloride $7 \cdot 03$, disodium hydrogen phosphate $7 \cdot 40$, magnesium sulphate $4 \cdot 00$, manganese sulphate $0 \cdot 18$, zinc carbonate $0 \cdot 10$, ferrous sulphate $0 \cdot 144$, copper sulphate $0 \cdot 015$, potassium iodate 0.001 .

$\dagger$ Vitamin mix $(\mathrm{mg} / \mathrm{kg}$ diet $)$ : nicotinic acid 60 , vitamin $B 12$ in mannitol 50 , calcium pantothenate 40 , thiamin hydrochloride 10 , riboflavin 10 , pyridoxin 10 , folic acid 5, D-biotin 1, vitamin K 1 , Rovimix E-25 300, Rovimix A-500 25, Rovimix A-500/D3 15, choline bitartrate 1800 .

subjects was calculated to be $26 \%$ and the appropriate weight of bread was therefore included in the test diets of the rats at the expense of starch-sucrose (carbohydrate) and albumen (protein). Vitamin and mineral mixes were also included to provide the requirements for rats, and $\mathrm{Fe}$ added as $\mathrm{FeSO}_{4}$ to the control diet to make the diets similar in $\mathrm{Fe}$ content. The composition of the diets is shown in Table 2.

Forty weanling male Wistar rats were individually caged in stainless-steel and plastic cages with metal-grid floors for several days, and fed the control diet ad lib. The animals were then randomly divided into four groups of ten and given the test diets for $14 \mathrm{~d}$. During this period food intakes were accurately measured and complete faecal collections carried out for each animal. Spilt food and faeces were separated by means of a nylon sieve. Urine was not collected as it contains negligible $\mathrm{Fe}$. The faeces were dried, ground and analysed for $\mathrm{Fe}$. The animals were weighed regularly, and at the end of the $14 \mathrm{~d}$ balance period. 


\section{Radioisotope experiment}

This was carried out to confirm the results of the balance study and also to compare two different methods of measuring Fe availability.

Forty weanling male Wistar rats were randomly divided into four groups of ten and housed individually in cages similar to the previous experiment. They were given control diet for 1 week ad lib. They were then trained to meal feed for $7 \mathrm{~d}$ by allowing them access to food pots at limited times. When this was successfully accomplished, the animals were fasted overnight and the following day were given test meals labelled with ${ }^{59} \mathrm{Fe}$ as follows.

The animals received either $3 \mathrm{~g}$ dried bread (white, brown or wholemeal), containing approximately $175 \mu \mathrm{g} \mathrm{Fe}$, made up into a paste with $5 \mathrm{ml}$ distilled water, or they were given $8 \mathrm{~g}$ cooked starch-sucrose paste $(50: 50, \mathrm{w} / \mathrm{w})$ with $175 \mu \mathrm{g} \mathrm{Fe}$ added as $\mathrm{FeSO}_{4}$. The $\mathrm{Fe}$ was labelled extrinsically by the addition of approximately $1 \mu \mathrm{Ci}^{59} \mathrm{Fe}$ (Amersham International Bucks)/rat (as ferric chloride solution, contributing negligible $\mathrm{Fe}$ ). The animals were given the meal, fasted for $5 \mathrm{~h}$ and then given control diet. They were fasted overnight and the next morning given $8 \mathrm{~g}$ starch-sucrose paste containing $175 \mu \mathrm{g} \mathrm{Fe}$, labelled extrinsically with approximately $2 \mu \mathrm{Ci}^{55} \mathrm{Fe}$ (Amersham International, Bucks)/rat (as $\mathrm{FeCl}_{3}$ solution, carrierfree). After a $5 \mathrm{~h}$ fast they were then given access to control diet ad lib.

Faeces were collected daily and the ${ }^{59} \mathrm{Fe}$ content measured using a Gamma Counter. After $10 \mathrm{~d}$ the animals were anaesthetized under diethyl ether and blood was removed by cardiac puncture and ${ }^{59} \mathrm{Fe}$ and ${ }^{55} \mathrm{Fe}$ content measured using a liquid-scintillation counter. The total ${ }^{59} \mathrm{Fe}$ and ${ }^{55} \mathrm{Fe}$ - content of the blood was calculated assuming that blood volume is $5.7 \%$ body-weight (Huang \& Bondurant, 1956).

\section{Analytical methods}

$\mathrm{Fe}$ analysis. Portions of dried, finely-ground samples were dry-ashed at $480^{\circ}$ in silica crucibles, the residue taken up in $5 \mathrm{ml}$ warm concentrated hydrochloric acid, and the solution diluted to an appropriate concentration for analysis by atomic absorption spectrometry.

Phytate analysis. This was carried out by a modification of the Holt method, as decribed by Davies \& Reid (1979).

Dietary fibre analysis. This was carried out using a modification (White \& Southgate, in preparation) of the Southgate method (Southgate, 1969).

Radioactivity measurements. Radioactivity in untreated samples was measured using a Philips Automatic Gamma Counter, PW 4580, with a $75 \mathrm{~mm} \times 75 \mathrm{~mm}$ sodium iodide crystal, Centre 535 , width 30 , gauge 20 , with a counting efficiency of approximately $3 \cdot 2 \%$.

Liquid-scintillation counting. Portions of $0.1 \mathrm{ml}$ heparinized blood were counted by a dual-label technique. The samples were digested with $1.5 \mathrm{ml}$ Soluene 350(Packard Instrument Ltd, Caversham, Berks)-propan-2-ol $(1: 1, \mathrm{v} / \mathrm{v})$ for $12 \mathrm{~h}$, and then $0.5 \mathrm{ml}$ hydrogen peroxide $(300 \mathrm{~g} / \mathrm{l})$ added and left to stand for $3 \mathrm{~h}$. Finally $15 \mathrm{ml}$ Instagel (Packard) $-0.5 \mathrm{M}-\mathrm{HCl}(9: 1$, $\mathrm{v} / \mathrm{v}$ ) was added and the vials counted in a Philips liquid-scintillation counter. The settings used were channel 1: attenuation 3.9, 40-1000; channel 2: attenuation 3.9, 40-200; channel 3: attenuation $0 \cdot 0,40-400$. Quench curves were prepared using channels ratio and values for the efficiency of counting were approximately $74 \%$ for ${ }^{59} \mathrm{Fe}$ and $12 \%$ for ${ }^{55} \mathrm{Fe}$.

\section{Statistical methods}

Differences between groups were tested by using unpaired $t$ tests (Snedecor \& Cochran, 1967). 
Table 3. Iron balance results for rats given diets containing bread for $14 d$

(Mean values with their standard errors)

\begin{tabular}{|c|c|c|c|c|c|c|c|c|}
\hline & \multicolumn{2}{|c|}{ Control } & \multicolumn{2}{|c|}{ White } & \multicolumn{2}{|c|}{ Brown } & \multicolumn{2}{|c|}{ Wholemeal } \\
\hline & Mean & SE & Mean & SE & Mean & SE & Mean & SE \\
\hline Faecal dry wt (g) & $8 \cdot 18^{*}$ & 0.29 & $11 \cdot 45^{\mathrm{a}}$ & $0 \cdot 37$ & $14 \cdot 62^{b}$ & 0.42 & $19 \cdot 84^{c}$ & 0.64 \\
\hline Total Fe intake $(\mathrm{mg})$ & $4 \cdot 84^{*}$ & $0 \cdot 10$ & $4 \cdot 26^{a}$ & $0 \cdot 11$ & $4 \cdot 00^{b}$ & 0.08 & $3.93^{\mathrm{b}}$ & 0.09 \\
\hline Total Fe excreted (mg) & $2 \cdot 63$ & 0.06 & $3.07^{\mathrm{a}}$ & $0 \cdot 11$ & $2 \cdot 77^{\mathrm{a}}$ & 0.09 & $2.99^{a}$ & 0.12 \\
\hline Fe absorbed (mg) & $2 \cdot 21^{*}$ & 0.24 & $1 \cdot 19^{\mathrm{a}}$ & 0.08 & $1 \cdot 22^{\mathrm{a}}$ & 0.06 & $0.93^{\mathrm{b}}$ & 0.05 \\
\hline Absorption & $0.455^{*}$ & 0.033 & $0 \cdot 279^{a}$ & 0.019 & $0 \cdot 307^{a}$ & 0.017 & $0 \cdot 240^{\mathrm{b}}$ & 0.017 \\
\hline
\end{tabular}

Mean values for control group were statistically significantly different from those for the bread diets: $* P<0.001$.

a. b.c Values with unlike superscript letters were statistically significantly different: $P<0.02$.

\section{RESULTS}

Balance experiment

The Fe intake and excretion over the $14 \mathrm{~d}$ experimental period are shown in Table 3 . The faecal dry weight increased significantly $(P<0.001)$ with each increase in fibre content. The $\mathrm{Fe}$ content of the control diet $(24.66 \mu \mathrm{g} / \mathrm{g})$ was marginally higher than the bread diets $(21.09-22.20 \mu \mathrm{g} / \mathrm{g})$ and consequently there was a significant difference $(P<0.001)$ in $\mathrm{Fe}$ intake between the control group and the three bread groups. As Fe excretion is related to intake, the group means for excreted Fe cannot be directly compared.

The absorption of Fe from the control diet was 0.45 , which was significantly higher $(P<0.001)$ than that from the bread diets, $0.24-0.31$. Differences between the bread diets were very small, but the wholemeal-bread groups absorbed slightly less $\mathrm{Fe}(P<0.02)$ than the brown-bread group.

\section{Isotope experiment}

The mean daily excretion of ${ }^{59} \mathrm{Fe}$, expressed cumulatively, for each group is shown in Fig. 1. As would be expected, dietary fibre affected transit time and initially excretion was most rapid in the wholemeal-bread group, and slowest in the white-bread group. There were no differences in excretion of ${ }^{59} \mathrm{Fe}$ between the three bread groups, but the control group excreted significantly less ${ }^{59} \mathrm{Fe}(P<0.001)$ over the $5 \mathrm{~d}$ period. Total excretion of ${ }^{59} \mathrm{Fe}$ over the $5 \mathrm{~d}$ was $31 \%$ of administered dose in the control group, and $45-48 \%$ of administered dose in the three bread groups as shown in Table 4.

Uptake of absorbed Fe into the blood is shown in Table 5. As in the faecal excretion results there were no significant differences in ${ }^{59} \mathrm{Fe}$ uptake between the three bread groups whose values ranged from $35-38 \%$ of administered dose, but uptake was significantly greater $(P<0.001)$ in the control group $\left(49 \%\right.$ of administered dose) given $\mathrm{FeSO}_{4}$.

There was greater inter-individual variation in the absorption of $\mathrm{Fe}$ from ${ }^{55} \mathrm{FeSO}_{4}$. In the control group $44 \%$ of the administered dose was found in the blood which was significantly less $(P<0.05)$ than the value of $53 \%$ of administered dose for the wholemeal group, but not significantly different from the brown ( $40 \%$ of administered dose) or white ( $41 \%$ of administered dose) bread groups. 


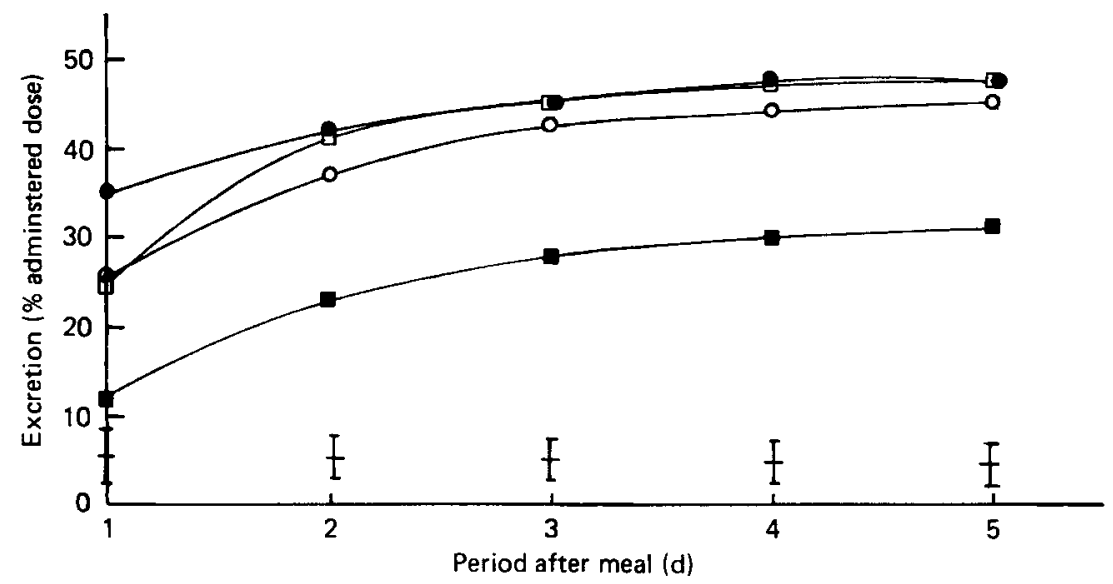

Fig. 1. Cumulative excretion of ${ }^{59} \mathrm{Fe}(\%$ administered dose) by rats given a single meal of dried bread extrinsically labelled with ${ }^{59} \mathrm{Fe}(\square)$, control; $(\square)$, white bread; $(\mathrm{O})$, brown bread; $(O)$, wholemeal bread. For details of diets, see p. 000 and Tables 1 and 2 . Points are mean values with their standard errors represented by vertical bars.

Table 4. Excretion of ${ }^{59} \mathrm{Fe}(\%$ administered dose $)$ by rats given a single meal of dried bread extrinsically labelled with ${ }^{59} \mathrm{Fe}$

(Mean values with their standard errors)

\begin{tabular}{lll}
\hline & \multicolumn{2}{c}{$\begin{array}{c}\text { Fe excretion (\% of } \\
\text { administered dose) }\end{array}$} \\
\cline { 2 - 3 } & Mean & SE \\
\hline Control & $30 \cdot 8^{*}$ & $1 \cdot 36$ \\
White & $47 \cdot 7$ & $2 \cdot 09$ \\
Brown & $45 \cdot 0$ & $2 \cdot 85$ \\
Wholemeal & $47 \cdot 4$ & $2 \cdot 21$ \\
\hline
\end{tabular}

* Significantly different from other groups: $P<0.001$.

Table 5. Iron in blood (\% administered dose) of rats given dried bread extrinsically labelled with ${ }^{59} \mathrm{Fe}$ or $\mathrm{FeSO}_{4}$ in a starch-sucrose paste extrinsically labelled with ${ }^{55} \mathrm{Fe}$ (Mean values with their standard errors)

\begin{tabular}{|c|c|c|c|c|}
\hline & \multicolumn{2}{|c|}{${ }^{59} \mathrm{Fe}$} & \multicolumn{2}{|c|}{${ }^{55} \mathrm{Fe}$} \\
\hline & Mean & SE & Mean & SE \\
\hline Control & $49 \cdot 3^{* *}$ & 0.98 & $44 \cdot 0$ & $2 \cdot 72$ \\
\hline White & $35 \cdot 2$ & 1.87 & $41 \cdot 0$ & 3.64 \\
\hline Brown & $35 \cdot 5$ & $1 \cdot 71$ & 39.6 & $3 \cdot 13$ \\
\hline Wholemeal & $37 \cdot 7$ & $2 \cdot 31$ & $52 \cdot 7^{*}$ & 2.53 \\
\hline
\end{tabular}

* Significantly different from other groups: * $P<0.05, \quad * * P<0.001$ 
Table 6. Summary of results of experiments investigating the effects of (a) primarily phytate, $(b)$ primarily fibre, and $(c)$ both fibre and phytate on iron absorption

\begin{tabular}{|c|c|c|c|c|}
\hline & $\begin{array}{l}\text { Experimental } \\
\text { model }\end{array}$ & Dietary manipulation & Results & Reference \\
\hline \multirow[t]{8}{*}{ (a) } & Human & $\begin{array}{l}\text { Addition of sodium phytate to } \\
\text { bread containing ferric and } \\
\text { ferrous salts }\end{array}$ & $\begin{array}{l}\text { Sodium phytate decreased } \\
\text { iron absorption }\end{array}$ & McCance et al. (1943) \\
\hline & Human & $\begin{array}{l}\text { Addition of } 26 \mathrm{~g} \text { wheat bran }(5 \mathrm{~g} \\
\text { phytate-phosporus } / \mathrm{kg}) \text { or } 26 \mathrm{~g} \\
\text { maize bran }(0 \mathrm{~g} \text { phytate } / \mathrm{kg}) \\
\text { to control diet }\end{array}$ & $\begin{array}{l}\text { No effect on } \mathrm{Fe} \\
\text { absorption }\end{array}$ & Sandstead et al. (1978) \\
\hline & Human & $\begin{array}{l}\text { Addition of sodium phytate } \\
(2.5 \mathrm{~g} / \mathrm{d} \text { per subject) or phytate } \\
\text { present in tanok bread for } \\
\text { several weeks }\end{array}$ & $\begin{array}{l}\text { Serum Fe fell initially } \\
\text { but then returned to } \\
\text { normal }\end{array}$ & Reinhold et al. (1973) \\
\hline & Rat & $\begin{array}{l}\text { Sodium phytate added to semi- } \\
\text { synthetic diet }(10 \mathrm{~g} / \mathrm{kg}) \\
\text { for } 21 \mathrm{~d}\end{array}$ & $\begin{array}{l}\text { Whole-body retention of } \\
\text { Fe fell }\end{array}$ & $\begin{array}{l}\text { Davies \& Nightingale } \\
(1975)\end{array}$ \\
\hline & Rat & Dephytinized bran $v$. raw bran & $\begin{array}{l}\text { Fe absorption higher with } \\
\text { dephytinized bran }\end{array}$ & Morris \& Ellis (1980) \\
\hline & Rat & $\begin{array}{l}\text { Sodium phytate added to basal } \\
\text { diet }(7-12 \mathrm{~g} / \mathrm{kg})\end{array}$ & $\begin{array}{l}\text { No effect on Fe } \\
\text { absorption }\end{array}$ & Cowan et al. (1966) \\
\hline & Rat & $\begin{array}{l}\text { Sodium phytate added to wheat- } \\
\text { based diets }(6.2-22.7 \mathrm{~g} / \mathrm{kg})\end{array}$ & $\begin{array}{l}\text { No effect on } \mathrm{Fe} \\
\text { absorption }\end{array}$ & Ranhotra et al. (1974) \\
\hline & In vitro & Sodium phytate plus metals & $\begin{array}{l}\text { Complexes formed at } \\
\text { pH } 7 \cdot 4\end{array}$ & Vohra et al. (1965) \\
\hline \multirow[t]{2}{*}{ (b) } & Rat & $\begin{array}{l}\text { Addition of cellulose to diet } \\
(160 \mathrm{~g} / \mathrm{kg}) \text { for } 9 \text { weeks }\end{array}$ & $\begin{array}{l}\text { No effect on } \mathrm{Fe} \\
\text { absorption }\end{array}$ & Tsai \& Lei (1979) \\
\hline & In vitro & $\begin{array}{l}\text { Bran and hemicellulosic fraction } \\
\text { of bran plus ferrous-Fe }\end{array}$ & $\begin{array}{l}\text { Very marked binding } \\
\text { at pH } 6.8\end{array}$ & $\begin{array}{l}\text { Ismail-Beigi et al. } \\
\text { (1977) }\end{array}$ \\
\hline \multirow[t]{7}{*}{ (c) } & Human & $\begin{array}{l}\text { Metabolic balance of white } \\
\text { bread v. brown bread }\end{array}$ & $\begin{array}{l}\text { Absorption from white } \\
\text { bread higher }\end{array}$ & $\begin{array}{l}\text { Widdowson \& McCance } \\
\text { (1942) }\end{array}$ \\
\hline & Human & $\begin{array}{l}\text { Enriched white bread } v \text {. unenriched } \\
\text { brown bread }\end{array}$ & $\begin{array}{l}\text { Absorption from brown } \\
\text { bread higher }\end{array}$ & $\begin{array}{l}\text { Callender \& Warner } \\
(1970)\end{array}$ \\
\hline & Human & $\begin{array}{l}70 \% \text { extraction flour } v .95-100 \% \\
\text { extraction flour for } 7-19 \text { weeks }\end{array}$ & $\begin{array}{l}\text { No difference in } \mathrm{Fe} \\
\text { absorption }\end{array}$ & Walker et al. (1948) \\
\hline & Human & $\begin{array}{l}\text { Addition of bran to wheat } \\
\text { bread }(7 \%)\end{array}$ & $\begin{array}{l}\text { Fe absorption reduced } \\
\text { by } 50 \%\end{array}$ & Björn-Rasmussen (1974) \\
\hline & Human & $\begin{array}{l}\text { Addition of } 31 \mathrm{~g} \text { wheat } \\
\text { fibre } / \mathrm{d} \text { for } 3 \text { weeks }\end{array}$ & $\begin{array}{l}\text { Significant fall in } \\
\text { serum Fe }\end{array}$ & Jenkins et al. (1975) \\
\hline & Rat & Addition of wheat bran to diet & Reduced Fe availability & Ranhotra et al. (1979) \\
\hline & In vitro & $\begin{array}{l}\text { Dephytinized wholemeal bread, } \\
\text { non-dephytinized bread, } \\
\text { bran and cellulose plus Fe }\end{array}$ & $\begin{array}{l}\text { Dephytinized bread higher } \\
\text { binding capacity } \\
\text { than non-dephytinized } \\
\text { bread. Also cellulose } \\
\text { binds Fe }\end{array}$ & Reinhold et al. (1975) \\
\hline
\end{tabular}

\section{DISCUSSION}

There are conflicting results in the literature concerning the effect of added sodium phytate on Fe absorption in man and the rat, as summarized in Table 6. McCance et al. (1943) showed that sodium phytate reduced Fe absorption in man from bread, but more recently Sandstead et al. (1978) found that the daily addition of $26 \mathrm{~g}$ wheat bran (containing $5 \mathrm{~g}$ phytate $/ \mathrm{kg}$ ) or maize bran (containing no phytate) to the diet had no effect on Fe absorption in man. In the rat, Davies \& Nightingale (1975) found the addition of sodium phytate to the diet reduced whole-body Fe retention, whereas Cowan et al. (1966) and Ranhotra et al. (1974) found it had no effect. 
Much of the work in this field is concerned with the effect of bran on Fe absorption, and it is difficult to assess the individual roles played by fibre and phytate in inhibiting $\mathrm{Fe}$ absorption. Tsai \& Lei (1979) showed that the addition of cellulose (up to $160 \mathrm{~g} / \mathrm{kg}$ diet) to the diet of rats had no effect on Fe absorption. Yet in vitro work of Ismail-Beigi et al. (1977) and Reinhold et al. (1975) has shown that bran, cellulose and hemicellulosic fractions of bran bind $\mathrm{Fe}$ strongly at neutral $\mathrm{pH}$, such as would be found in the jejunum.

Results from both experiments described in this paper show a higher Fe absorption from $\mathrm{FeSO}_{4}$ than from $\mathrm{Fe}$ present in bread whether results are expressed as $\mathrm{mg} \mathrm{Fe}$ absorbed or percentage $\mathrm{Fe}$ absorption. The balance study showed a small difference in Fe absorption between the three bread diets. The brown-bread group appeared to have absorbed significantly more $(P<0.02)$ iron, $31 \%$ of administered dose, than the wholemeal-bread group, $24 \%$ of administered dose. Since the value for absorption for the white-bread group, $28 \%$ of administered dose, fell between the brown- and wholemeal-bread groups, but the fibre content was lowest, it is unlikely that the difference between Fe absorption from brownand wholemeal-bread diets is related to the fibre content of the diet.

The radioisotope experiment clearly demonstrated that there was no difference in $\mathrm{Fe}$ absorption between the three breads. It can therefore be concluded that the addition of wheat-bran fibre (in amounts similar to those found in commercially-available bread) to flour of similar phytate concentration had no effect on Fe absorption in the rat in shortor long-term experiments. This supports the findings of Tsai \& Lei (1979) that the addition of cellulose $(160 \mathrm{~g} / \mathrm{kg}$ diet $)$, one of the components of wheat bran, to the diet had no effect on $\mathrm{Fe}$ availability to the rat. $\mathrm{Fe}$ absorption from control diets containing $\mathrm{FeSO}_{4}$ was higher which may be because the $\mathrm{Fe}$ from $\mathrm{FeSO}_{4}$ is more available than the $\mathrm{Fe}$ in the bread, or it may be the absence of phytate in the control diet which rendered the dietary Fe more available, or both.

The author would like to thank Dr J. H. Cummings of the Dunn Clinical Nutrition Centre, Cambridge for kindly supplying the bread, Ms V. Simmonds for technical assistance, and Dr D. A. T. Southgate for advice in the preparation of this paper.

\section{REFERENCES}

Björn-Rasmussen, E. (1974). Nutr. Metab. 16, 101.

Callender, S. T. \& Wamer, G. T. (1970). Lancet i, 546.

Cowan, J. W., Esfahani, M., Salji, J. P. \& Azzam, S. A. (1966). J. Nutr. 90, 423.

Davies, N. T. \& Nightingale, R. (1975). Br. J. Nutr. 34, 243.

Davies, N. T. \& Reid, H. (1979). Br. J. Nutr. 41, 579.

Huang, K. \& Bondurant, J. H. (1956). Am. J. Physiol. 185, 441.

Ismail-Beigi, F., Faradji, B. \& Reinhold, J. G. (1977). Am. J. clin. Nutr. 30, 1721.

Jenkins, D. J. A., Hill, M. S. \& Cummings, J. H. (1975). Am. J. clin. Nutr. 28, 1408.

McCance, R. A., Edgecombe, C. N. \& Widdowson, E. M. (1943). Lancet ii, 126.

Morris, E. R. \& Ellis, R. (1980). J. Nutr. 110, 2000.

Ranhotra, G. S., Lee, C. \& Geiroth, J. A. (1979). Nutr. Rep. int. 17, 851.

Ranhotra, G. S., Loewe, R. J. \& Puyat, L. V. (1974). Cereal Chem. 51, 323.

Reinhold, J. G., Ismail-Beigi, F. \& Faradji, B. (1975). Nutr. Rep. int. 12, 75.

Reinhold, J. G., Nasr, K., Lahimgar Zadeh, A. \& Hedayati, H. (1973). Lancet i, 283

Sandstead, H. H., Mŭnoz, J. M., Jacob, R. A., Klevay, L. M., Reck, S. J., Logan, G. M., Jnr, Dintzis, F. R., Inglett, G. E. \& Shuey, W. C. (1978). Am. J. clin. Nutr. 31, 5180.

Snedecor, G. W. \& Cochran, W. G. (1967). Statistical Methods, 6th ed. Ames, Iowa: Iowa State University Press. Southgate, D. A. T. (1969). J. Sci. Fd Agric. 20, 331.

Tsai, R. C. Y. \& Lei, K. Y. (1979). J. Nutr. 109, 1117.

Vohra, P., Gray, G. A. \& Kratzer, F. H. (1965). Proc. Soc. exp. Biol. Med. 120, 447.

Walker, A. R. P., Fox, F. W. \& Irving, J. T. (1948). Biochem. J. 42, 452.

Widdowson, E. M. \& McCance, R. A. (1942). Lancet i, 588. 